\title{
Partitioning of calcium in human milk after freezing and thawing
}

\author{
Jacqueline C. Kent* ${ }^{*}$, Peter G. Arthur, Peter E. Hartmann \\ Biomedical, Biomolecular and Chemical Sciences, The University of Western Australia, \\ M310, 35 Stirling Highway, Crawley WA 6009, Australia
}

Received 3 June 2008 - Accepted 26 November 2008

\begin{abstract}
Minimal calcium in fresh human milk occurs in the fat. Freshly-collected milk was partitioned into fat and skim milk fractions, and the skim milk was partitioned into a colloidal fraction containing casein micelles, and a diffusible fraction. This fractionation was repeated after freezing and thawing three times over 14 days. Up to $51 \%$ of the total calcium was found in the fat layer of the milk after sequential freezing and thawing. We aimed to contribute to the understanding of the calcium interactions that cause this redistribution. Freezing and thawing disrupts the fat globule membrane and releases fatty acids. We calculated that the amount of fatty acids generated by freezing and thawing of the milk would bind only a minor proportion of the calcium that was transferred to the fat layer. In addition, the calcium that appeared in the fat layer was not removed from the colloidal fraction and therefore there was no evidence of disruption of the casein micelles. This suggests that the majority of the calcium that appears in the fat of human milk after freezing and thawing can be attributed to increases in the binding of calcium to the fat globule membranes.
\end{abstract}

calcium / human milk / freezing / thawing / milk fat globule membrane

\begin{abstract}
摘要 - 冻融后钙在人乳中的分配。新鲜人乳中钙存在于脂肪中。将收集的新鲜人乳分离成 乳脂肪和脱脂乳, 脱脂乳又分离成含有酪蛋白胶束的胶体部分和溶液部分。鲜人乳样品在 $14 \mathrm{~d}$ 内反复冻融 3 次后按照上述方法分离成不同的馏分。经过连续的冻融后, $51 \%$ 钲在脂 肪层中。本研究的目的是了解冻融引起钙重新分配的原因。冻融作用打破了脂肪球, 使得脂 肪酸游离出来。根据冻融产生游离脂肪酸量来推算, 只有很少部分与脂肪酸结合的钙迁移到 脂肪层。此外, 脂肪层的钲并不是从酪蛋白胶束中迁移来的, 而且没有证据证明酪蛋白胶束 的破裂。因此, 可以认为冻融后出现在人乳脂肪中的钙主要是由于脂肪球膜对钲束缚力的增 加。
\end{abstract}

\section{钙 / 人乳 / 冷冻 / 融化 / 乳脂肪球膜}

Résumé - Répartition du calcium dans le lait humain après congélation et décongélation. Dans le lait humain à l'état frais, très peu du calcium se trouve dans la matière grasse. Du lait humain fraîchement récolté a été écrémé, et le lait écrémé séparé entre une fraction colloïdale, contenant les micelles de caséine, et une fraction soluble. Ce fractionnement était répété trois fois après congélation et décongélation sur une période de 14 jours. Jusqu'à $51 \%$ du calcium total s'est trouvé dans la matière grasse après congélation et décongélation consécutives. Cette étude a eu pour but de contribuer à la compréhension des causes de cette redistribution, à travers les interactions avec le calcium. La congélation-décongélation provoque la rupture de la membrane du globule gras et libère les acides gras. Nous avons calculé que la quantité des acides gras

* Corresponding author (通讯作者): Jacqueline.Kent@uwa.edu.au 
qui sont produits après congélation et décongélation du lait ne peut lier qu'une petite proportion du calcium qui était transféré à la surface de la couche lipidique. De plus, le calcium qui apparaît dans la matière grasse ne provient pas de la fraction colloïdale, et il n'y a donc pas de signe de la rupture des micelles de caséine. Ceci suggère que la majeure part du calcium qui apparaît dans la matière grasse du lait humain après congélation et décongélation peut être attribuée à une augmentation de la liaison du calcium aux membranes des globules gras.

calcium / lait humain / congélation / décongélation / membrane du globule gras

\section{INTRODUCTION}

An adequate intake of calcium from human milk is essential for mineralisation of the developing skeleton of the breastfed infant. Therefore, accurate measurement of the concentration of calcium in human milk is important, and requires consideration of the alterations in the distribution of calcium between fractions of the milk during processing of milk samples.

Calcium is bound to casein micelles in the colloidal fraction of milk, and also occurs in the diffusible (not protein bound) fraction of milk predominantly as ionized calcium and calcium citrate [9]. The concentration of calcium phosphate in the diffusible fraction of milk is very low (about $\left.0.4 \mathrm{mmol} \cdot \mathrm{L}^{-1}[9]\right)$ and does not make a significant contribution to the total concentration of calcium in the milk.

Assessment of the concentration of calcium in human milk may be affected by the collection and processing of the samples. Non-fat components of human milk are usually measured in samples of milk that have been frozen, thawed, and centrifuged to remove the fat so that samples of skim milk can be analysed. This will be satisfactory if the calcium does not occur in the fat layer of the milk.

The proportion of total calcium found in the fat layer of freshly-collected human milk ranges from $0 \%$ to $16 \%[5,6,9]$. However, after freezing and thawing, an increase in the amount of calcium in the fat layer has been found $[4,9]$. The calcium interactions resulting from freezing and thawing are unclear. Neville et al. [9] suggested three possible explanations for the increase in calcium in the fat layer: (1) calcium binding to free fatty acids exposed when the milk fat globule membrane is broken; (2) binding of calcium to the lipid droplet as occurs in homogenized bovine milk; or (3) binding of casein to the milk fat globule membrane. Fransson and Lönnerdal have partitioned the fat fraction of human milk and found that $67 \%$ of the calcium in the fat was associated with the outer fat globule membrane, $24 \%$ with the inner fat globule membrane and 8-9\% with the core triacylglycerols $[5,6]$.

We aimed to determine the proportion of calcium in the fat layer of freshlycollected human milk samples in order to confirm if it is insignificant [9] or more than $10 \%[5,6]$; to assess the redistribution of calcium in human milk samples after successive freezing and thawing; and to try to elucidate the calcium interactions that cause the redistribution.

\section{MATERIALS AND METHODS}

Five mothers in established lactation gave informed consent for the manual expression of milk samples into $5 \mathrm{~mL}$ vials that were immediately placed on ice. In fresh, whole milk samples, $\mathrm{pH}$ was measured on a Nova 5 blood gas analyser (Nova Biomedical, Waltham, MASS, USA). After digestion of $25 \mu \mathrm{L}$ of whole milk with nitric acid the concentration of calcium was measured by atomic absorption spectrophotometry using conditions similar to those recommended by 
Table I. pH in whole milk, and calcium in skim milk and ultrafiltrate prepared when freshly collected (day 0) or after consecutive freezing and thawing on days 4, 7 and 14.

\begin{tabular}{llll}
\hline Day & \multicolumn{1}{c}{$\mathrm{pH}$} & \multicolumn{2}{c}{ Calcium concentration $(\mathrm{mM})$} \\
& & \multicolumn{1}{c}{ Skim } & Ultrafiltrate \\
\hline 0 & $7.36 \pm 0.02$ & $6.43 \pm 0.37$ & $5.00 \pm 0.28$ \\
4 & $6.78 \pm 0.03^{* *}$ & $5.66 \pm 0.35^{*}$ & $4.18 \pm 0.36^{* *}$ \\
7 & $6.97 \pm 0.04^{* *}$ & $4.88 \pm 0.47^{*}$ & $3.52 \pm 0.31^{*}$ \\
14 & $6.59 \pm 0.03^{* *}$ & $2.88 \pm 0.38^{* *}$ & $1.83 \pm 0.40^{* *}$ \\
\hline
\end{tabular}

Values are mean $\pm \mathrm{SEM}, n=5$.

Significantly different (paired $t$-test) from previous sampling time: $* P<0.02, * * P<0.001$.

the manufacturer of the atomic absorption spectrophotometer (Varian Techtron Pty. Ltd., Melbourne, Australia) using lanthanum chloride $(0.2 \% \mathrm{v} / \mathrm{v})$ as a releasing agent, a calcium/magnesium hollow cathode lamp and a lean air-acetylene flame. One aliquot of the milk was defatted by centrifugation in $250 \mu \mathrm{L}$ microcentrifuge tubes $(7000 \times g, 5 \mathrm{~min}$, room temperature), the fat layer was removed by slicing the tube below the fat layer, and the concentration of calcium was measured in the skim milk. Within $4 \mathrm{~h}$ of collection another aliquot was separated into colloidal and diffusible (ultrafilterable) fractions at room temperature using an Amicon MPS-1 System containing a YMT ultrafiltration membrane (MW cutoff $30000 \mathrm{~g} \cdot \mathrm{mol}^{-1}$ ) (Amicon Corporation, Danvers, MASS, USA). The colloidal fraction contains caseins, lactoferrin and immunoglobulins, and the ultrafiltrate contains small molecular weight proteins such as lysozyme and $\alpha$-lactalbumin. The concentration of calcium was measured in the ultrafiltrate. The remainder of the whole milk sample was frozen at $-15^{\circ} \mathrm{C}$. On days 4,7 and 14 after collection, the milk samples were thawed, aliquots defatted, partitioned and calcium concentration measured in the skim milk and ultrafiltrate, and the remainder of the sample was refrozen.

A physicochemical model of ion interaction using intrinsic association constants and adjusted for the calculated ionic strength as described by Holt et al. [8] was created using Stella II (1990-1994, High Performance Systems, Inc., Hanover, NH 03755, USA).

\section{RESULTS AND DISCUSSION}

The concentration of total calcium in the fresh milk samples was $5.95 \pm$ $0.34 \mathrm{mmol} \cdot \mathrm{L}^{-1}$ (mean $\pm \mathrm{SEM}$ ), which is not significantly different from the concentration of calcium measured in the skim milk (Tab. I). This result contrasts with those of Fransson and Lönnerdal [5,6] who found $10-16 \%$ of the total calcium in the fat layer of fresh milk samples, but is consistent with the results of Neville et al. [9]. The calcium in the fat increased to $4.6 \pm$ $4.4 \%, 16.4 \pm 4.4 \%$ and $51.2 \pm 2.8 \%$ of the total calcium at 4,7 and 14 days, respectively, after consecutive freezing and thawing. Each successive freezing and thawing caused a significant decrease in the concentration of calcium in the skim milk (Tab. I). There were concurrent decreases in the concentration of calcium in the casein-free ultrafiltrate. The equivalent loss of calcium from both the skim milk and the ultrafiltrate indicates that the calcium in the colloidal fraction (bound to casein) was not affected by freezing and thawing. If casein were binding to the milk fat 
globule membrane fraction after freezing and thawing as has been suggested [9] a loss of calcium from the colloidal fraction would have been expected.

The human milk fat globule was thought to consist of triacylglycerols surrounded by a lipophilic inner membrane with few phospholipids and a hydrophilic outer membrane with a higher proportion of phospholipids [3]. Chappell et al. [2] have provided evidence that freezing and/or thawing ruptures the fat globule membrane. This would release triacylglycerols and expose the phospholipids of the fat globule membranes. Bitman et al. [1] showed that in samples of human milk that were extracted immediately after collection, $99 \%$ of the fat was in the form of triacylglycerol and only $0.08 \%$ $\left(0.1 \mathrm{mmol} \cdot \mathrm{L}^{-1}\right)$ was in the form of free fatty acids. However, after storage at $-20{ }^{\circ} \mathrm{C}$ for 6 to 18 months and freezing and thawing the samples twice, free fatty acids comprised $16.66 \%$ of the total fat $\left(27 \mathrm{mmol} \cdot \mathrm{L}^{-1}\right)$. Fatty acids $(\mathrm{RCOOH})$ are weak acids with a $\mathrm{pK}$ of $\sim 4.85$. Thus the ionised form $\left(\mathrm{RCOO}^{-}\right)$is the predominant species in aqueous solutions at a $\mathrm{pH}$ above the $\mathrm{pK}$ of the acid. This may contribute to the decrease in $\mathrm{pH}$ after freezing and thawing (Tab. I). Using an association constant of 15 for $\mathrm{Ca}^{2+}$ and $\mathrm{RCOO}^{-}$[8] in the physicochemical model of ion interaction predicts that this would result in an increase in $\mathrm{RCOOCa}^{+}$of $0.25 \mathrm{mmol} \cdot \mathrm{L}^{-1}$. This is only $10 \%$ of the calculated change in the calcium concentration in the fat fraction. Therefore, the suggestion that calcium binding to free fatty acids exposed when the milk fat globule membrane is broken [9] can explain only some of the calcium in the fat fraction of the milk after freezing and thawing.

These calculations suggest that the remainder of the loss of calcium to the fat fraction can be attributed to binding of calcium to the fat globule membranes as observed by Fransson and Lönnerdal [6].
These authors suggested that the calcium was loosely attached electrostatically to the membranes. Since interactions that are stabilized by ionic bonds will be strengthened at low temperatures [7], it is likely that lower temperatures will strengthen the attachment of calcium to the phospholipids of the fat globule membranes [5,6]. Based on these findings, it follows that minimal calcium will be associated with the fat fraction of milk if samples are processed at room temperature immediately after collection.

\section{CONCLUSION}

These results show that there is minimal calcium in the fat layer of freshlycollected human milk samples. Optimal conditions for assessment of the concentration of calcium in human skim milk is to centrifuge freshly-collected samples at room temperature and remove the skim milk before freezing. After freezing and thawing, calcium appears in the fat layer. Our calculations show that calcium binding to free fatty acids can account for only a small fraction of the calcium that appears in the fat fraction. These results are consistent with binding of calcium to the phospholipids of the fat globule membranes.

Acknowledgements: The authors thank the mothers who donated milk samples. Financial support from Medela AG is gratefully acknowledged.

\section{REFERENCES}

[1] Bitman J., Wood D.L., Mehta N.R., Hamosh P., Hamosh M., Lipolysis of triglycerides of human milk during storage at low temperatures: a note of caution, J. Pediatr. Gastroenterol. Nutr. 2 (1983) 521-524.

[2] Chappell J.E., Clandinin M.T., McVey M.A., Chance G.W., Free fatty-acid content of human-milk: physiologic significance and artifactual determinants, Lipids 20 (1985) 216-221. 
[3] Fransson G.-B., Lönnerdal B., Iron in human milk, J. Pediatr. 96 (1980) 380-384.

[4] Fransson G.-B., Lönnerdal B., Zinc, copper, calcium, and magnesium in human milk, J. Pediatr. 101 (1982) 504-508.

[5] Fransson G.-B., Lönnerdal B., Distribution of trace elements and minerals in human and cow's milk, Pediatr. Res. 17 (1983) 912-915.

[6] Fransson G.-B., Lönnerdal B., Iron, copper, zinc, calcium, magnesium in human milk fat, Am. J. Clin. Nutr. 39 (1984) 185-189.
[7] Hochachka P.W., Somero G.N., Strategies of biochemical adaptation, WB Saunders Company, Philadelphia, USA, 1973.

[8] Holt C., Dalgleish D.G., Jenness R., Calculation of the ion equilibria in milk diffusate and comparison with experiment, Anal. Biochem. 113 (1981) 154-163.

[9] Neville M.C., Keller R.P., Casey C., Allen J.C., Calcium partitioning in human and bovine milk, J. Dairy Sci. 77 (1994) 19641975. 